UDC 519.143

doi: 10.32620/reks.2020.2.06

Yu. PENKIN ${ }^{1}$, G. KHARA ${ }^{1}$, A. FEDOSEEVA ${ }^{2,3}$

${ }^{1}$ National Pharmaceutical University, Ukraine

${ }^{2}$ Kharkiv Radiotechnical College, Ukraine

${ }^{3}$ National Aerospace University “Kharkiv Aviation Institute”, Ukraine

\title{
MODELING OF VIBRATIONAL PROCESSES IN DISCRETE MATRIX STRUCTURES APPROACH
}

\begin{abstract}
In the article are presented general principles of modeling vibrations in discrete structures formed in the form of special matrix forms of the Latin square (Sudoku type) are presented. The signs of structural and functional self-similarity for the matrix structures of standard Sudoku grids are formulated. It is shown that the structural principle can be interpreted as the implementation of the second iteration in the scale scaling algorithm characteristic of fractal objects. The signs of functional self-similarity of structures include the property of additive conservation of grid shapes to the requirements of Sudoku, which is formulated as a theorem. It is proved that the matrix sums of Sudoku constants and grids of arbitrary sizes, obtained taking into account the introduced cyclic ranking rule, will satisfy the three required Sudoku requirements. It is determined that by performing a given sequence of group shift operators, it is possible to establish a specific scenario for dynamically changing the state of a structure on a discrete time scale. It has been established that the evolution operators of lineartype group translations lead to matrix transformations of Sudoku grids from the set of equivalent ones (concerning the original ones), and the vortex-type group shifts operators to matrix transformations from many essentially different networks. The modes of harmonic, chaotic, and hybrid vibrations for structures of arbitrary size are considered. The requirements for transformations of the operators of the evolution of structures that provide the implementation of the considered modes are formulated. The results of modeling chaotic oscillatory processes by cycles of states of a discrete system that form similarities of attractor paths are analyzed. The principle of synchronization of chaotic states of matrix structures is established. The possibility of simulating the modes of beatings of oscillations in discrete cellular structures organized in the form of two-level matrix forms is substantiated. Specific examples show the results of simulating beatings of oscillations in cycles of changing states of a discrete system for two types of beats: similar to the result of a superposition of harmonic vibrations at multiple frequencies in the theory of radio signals, as well as noise-like beats.
\end{abstract}

Keywords: data discrete structure; Sudoku grid; signs of self-similarity; operators of matrix transformations; oscillations modes; deterministic chaos; noise-like beats.

\section{Introduction}

The dynamic systems are the systems that states change overtime in accordance with the established rules of the evolution operator [1]. In traditional there are share systems with continuous and discrete time of evolutions (flows and cascades). First type of system in literature are like continuous systems, and second type (given the way of describing time) - like discrete. However, in addition to the discrete time of evolution, a truly discrete system must also consist of spatially and functionally focused elements, i.e. be a discrete structure.

A dynamic system is also said to be, if we can point the setoff values, called dynamic values and characterizing the state of the system. Their values in the next time moment can be determined from the source using evolution operator rules. If state of the system defined by a set of $\mathrm{N}$ quantities, then the dynamics of its state change in time can be represented as the move- ment of a point along a trajectory in an $\mathrm{N}$-dimensional phase space, which called phase trajectory. Initially, purely Newtonian content was invested in the concept of a dynamic system, meaning a set of bodies connected by force interactions and obeying a system of differential equations. The modern concept of dynamic system is fuller and means that we can set the evolution operators in any way. Particularly, for systems with discrete time it will be like recurrence mappings or difference equations (with use different discrete transformations), and for discrete systems - through the rules of mutual permutations of structural elements.

Usually, the structure of a discrete dynamic system can be specified in the form of a special matrix form Latin square Sudoku type (from Japanese: 数独 - separate number). Moreover, the numbers used in its cells can be considered as indicators of an indicator of some qualitative factor (color, sound, density, warmth, area, count of defects or microobjects, probabilities etc.).

(C) Yu. Penkin, G. Khara, A. Fedoseeva, 2020 
Fig. 1, a rerepresented example of three-dimensional discrete structure models (Fig. 1, b) and puzzle breakdown of a homogeneous array of objects (Fig. 1, c) in the Sudoku square fragment (Fig. 1, a).

\begin{tabular}{|l|l|l|}
\hline 9 & 7 & 4 \\
\hline 8 & 6 & 3 \\
\hline 1 & 5 & 2 \\
\hline
\end{tabular}

a)

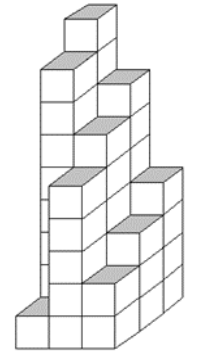

b)

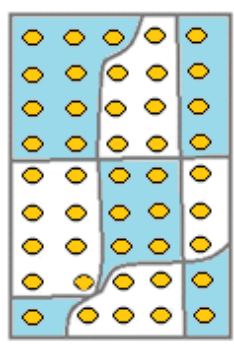

c)
Fig. 1. The examples of discrete structure models

The discrete structures are one of dynamic systems type, for the description may be used the representations of their specific states. In this case the phase area means like set of all permissible system states in the dynamics of their changes over time. Thus, the discrete structure is characterized by its initial state and the law (specified by the evolution operator), according to which the system goes from the initial state to the subsequent. If evolution operator in the time scale is set so that the structure after change cycle periodically returns to the same state, then we can talk about observing the oscillatory process in the system.

Study of various types of vibrations (own, forced, self-oscillations, parametric) in different type of systems always gives a big attention. Note that in nonlinear dynamics, nonlinear models are used to study the properties of dynamical systems, which usually are described by differential equations for systems with continuous time and recurrent (or discrete) mappings for discrete time systems. However, dynamic models of discrete structures in which evolution operators are specified like algorithms (not the formula ratios, for example at [2]), in the modern literature are not represented.

In the [3] the model of the oscillation simulator indiscrete structures constructed in the form of Sudoku grids was first proposed, the dynamics of changes in discrete time is described by specially introduced evolution operators of group translations of linear and vortex types. In the modeling base will substantiated the manifestations of deterministic chaos regimes in oscillations of such discrete structures conditions. However, in the [1] big attention paid for of Sudoku classic matrixes with $9 \times 9$ size. The aim of this paper are generalization of the principles of modeling vibrations into discrete structures of Sudoku type of arbitrary sizes and justification of the possibility of simulating the modes of beat- ings of oscillations in discrete cell structures organized in the form of two-level matrix forms.

\section{The signs self-similarity for matrix structures of standard Sudoku grids}

First of all, it should be indicated that as necessary conditions for the formation of digital grids of the $\mathrm{Su}$ doku type [1], signs of both structural and functional self-similarities. Here «structural» self-similarity must be understood like local scaling of geometric form of grids, and «functional» - in sense of manifestation of scale invariance in numerical sequences, which fill up these matrix forms.

Most clearly sign of structural self-similarity of Sudoku type can imagine based on case studies. In the Fig. 2 consistently represents the grids with different sizes: 4x4 (Fig. 2, a), 9x9 (Fig. 2, b) and 16x16 (Fig. 2, c). As can be seen, in the general case the natural number $n \geq 2$ determines the linear size of a small base square, and number $n^{2}$ - the count of elements in this square and, at the same time, the count of small squares in general field $\mathrm{n}^{2} \mathrm{xn}^{2}$ size. Exploring Sudoku as a mathematical object usually used the accepted terms for matrix forms: grid row, grid column, stripe - a block row of adjacent small squares horizontally and a stack a block column of adjacent small squares vertically. Another word, arbitrarily given natural number $\mathrm{n}$ is a setting for the linear size of the small square of the grid field, as well as the number of stripes and the number of stacks of the total field. This structural principle can be interpreted as the implementation of the second iteration in a multiple scaling algorithm for fractal objects [4].

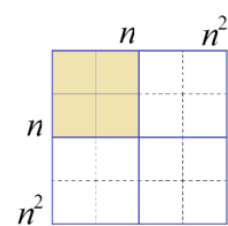

a)

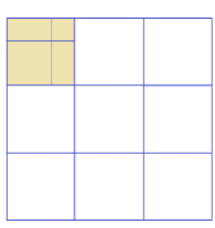

b)

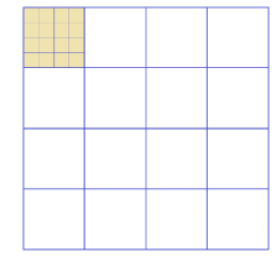

c)
Fig. 2. Structural self-similarity of Sudoku fields

A sign of functional self-similarity refers to the choice of a discrete algorithm «sowing» of natural numbers in the constructed grid fields. Note that it differs significantly from the possibility of scaling variables in functional dependencies or equations using proportional coefficients that is observed in fractal theory [4]. However this features don't allow rejecting the fact that for Sudoku matrices functional self-similarity is observed. Should be reminded, that the Sudoku matrix field (according to accepted requirements) is filled with natural numbers from set $\left\{1,2,3, \ldots, n^{2}\right\}$ and is a Latin Euler`s 
square with an additional property: in the common grid field each of $\mathrm{n}^{2}$ adjacent small squares contains once all natural numbers from the set from 1 to $\mathrm{n}^{2}$. According [3] it is convenient to introduce the standard form of Sudoku grids into the analysis, for which the rows (from left to right) are filled with ranked data, taking into account the closed sequence of digits in the cycle. In the upper left cell of the upper grid strip is located 1 (Fig. 3, a), in the upper left cell of the second from the top of the strip is 2, and so on to the lower strip, in the upper left cell of which the n number. Ranked rows of natural numbers fill the cells of each row, which taking into account the limited value $\mathrm{n}^{2}$ cycles according an algorithm similar to discrete clockwork (Fig. 3, b). After $\mathrm{n}^{2}$ follows again $1,2,3, \ldots$ etc. This operation will be called cyclic ranking. Small squares of the first left stack of the grid are filled with ranked rows according to the specified algorithm with line-by-line continuation. For clarity on Fig. 3, c and Fig. 3, d an example is given for the standard grid of classic Sudoku with $n=3$.

As seen from Fig. 3 built standard grids $\left(\mathrm{L}_{0}\left(\mathrm{n}^{2}\right)\right)$, satisfy all three Sudoku requirements, and their size and filling format are determined only by the parameter $\mathrm{n}$. It is the possibility of determining Sudoku nets using one parameter that is basic for the manifestation of their functional self-similarity.

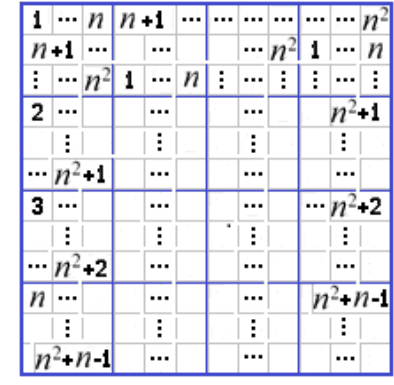

a)

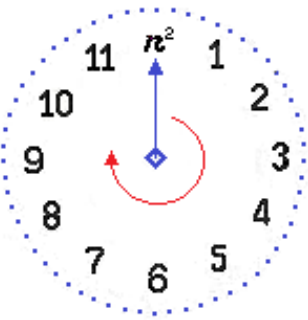

c)

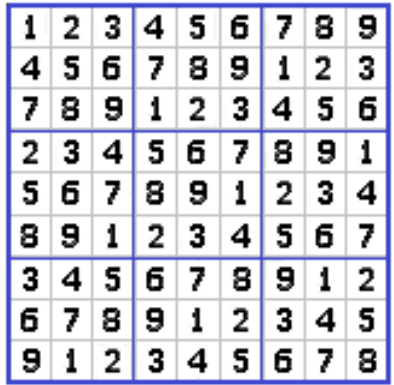

b)

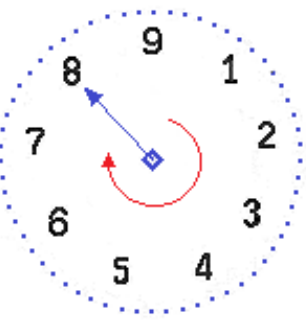

d)
Fig. 3. Sudoku grid standard form

Sudoku requirements, expressed in terminological form as: «all rows, all columns and all adjacent small squares of the structure contain exactly once all natural numbers from 1 to $\mathrm{n}^{2}$ », in «digital» modeling can be written using the well-known formula for the finite sum of a series of natural numbers in the form of the following mathematical relations:

$$
\left\{\begin{array}{c}
\sum_{i}^{n^{2}} a_{i j}=\frac{n^{2}\left(n^{2}+1\right)}{2}, \text { for } j=1,2, \ldots, n^{2} ; \\
\sum_{j}^{n^{2}} a_{i j}=\frac{n^{2}\left(n^{2}+1\right)}{2}, \text { for } i=1,2, \ldots, n^{2} ; \\
\sum_{i, j} a_{i j}=\frac{n^{2}\left(n^{2}+1\right)}{2}, \text { for each small square. }
\end{array}\right.
$$

where $a_{i j}$ - grid matrix elements.

Also, the features of functional self-similarity include the property of additive conservation of grid shapes to Sudoku requirements, which can be formulated as a theorem: the matrix sum of an arbitrary Sudoku grid and constant $C_{m}$ for $1 \leq m \leq n^{2}$ found taking into account the cyclic ranking rule, satisfies the mandatory requirements of Sudoku.

Evidence. Without loss of generality, we prove the theorem for standard matrix forms $\left(\mathrm{L}_{0}\left(\mathrm{n}^{2}\right)\right)$.

Moreover, understanding the matrix representation of the constant $\mathrm{C}_{\mathrm{m}}$ : matrix $\mathrm{C}_{\mathrm{m}}=\left|\begin{array}{ccc}\mathrm{m} & \mathrm{m} & \mathrm{m} \\ \ldots & \ldots & \ldots \\ \mathrm{m} & \mathrm{m} & \mathrm{m}\end{array}\right|$.. consider a special case for $\mathrm{L}_{0}\left(\mathrm{n}^{2}\right)$ at $\mathrm{n}=2$, like easiest to analyze. Here the matrix summation operation will be applied in the usual sense when the elements of the final matrix $\mathrm{L}_{\Sigma}^{\mathrm{m}}(4)$ equal to the algebraic sum of the corresponding elements of the two terms of the matrixs: $a_{i j}^{\Sigma}=a_{i j}^{(1)}+a_{i j}^{(2)}$, where $a_{i j}^{(1,2)}$ elements of the first and second matrices, respectively. However, the result of each summation $\mathrm{a}_{\mathrm{ij}} \sum$ in the final matrix provided $\mathrm{a}_{\mathrm{ij}}^{\Sigma}>\mathrm{n}^{2}$ must be adjusted according to the cyclical ranking rule. In turn, we consider all four possible options for $1 \leq \mathrm{m} \leq 4$ :

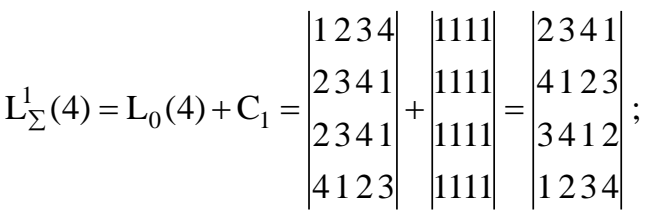

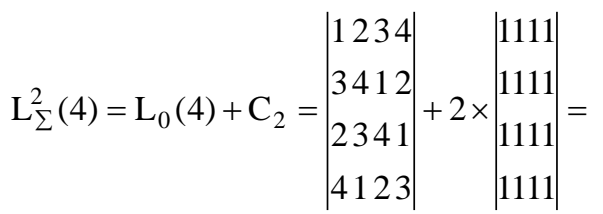

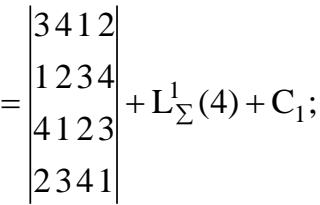




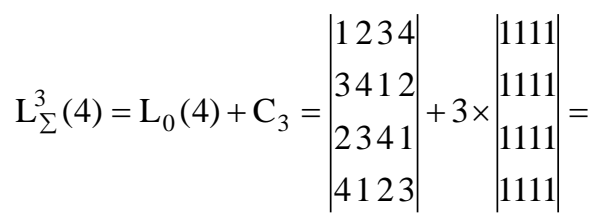

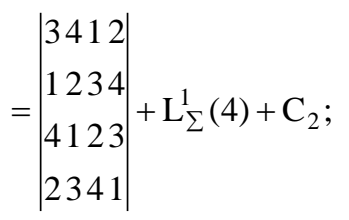

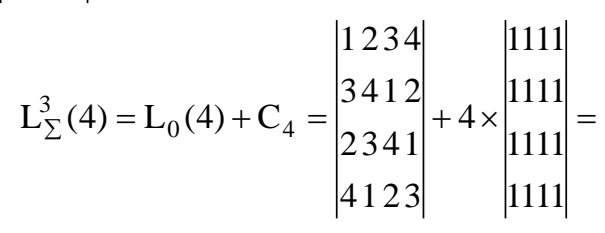

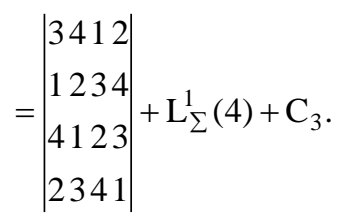

It is easy to perform similar operations of summing constants with matrices $\mathrm{L}_{0}(9)$ and $\mathrm{L}_{0}(16)$, and then inductively generalize to the case of arbitrary choice $\mathrm{L}_{0}\left(\mathrm{n}^{2}\right)$. Of course, the analysis for standard-type grids has a natural extension to other types of grids. Thus, the matrix sums of arbitrary (with respect to size and type) Sudoku nets and constant $C_{m}$ for $1 \leq m \leq n^{2}$, obtained taking into account the rules of cyclic ranking, will satisfy the three mandatory requirements of Sudoku. Q.E.D.

As can be seen from (2) - (5), the resulting matrices really satisfy the requirements of Sudoku. Moreover, the addition of odd constants to $\mathrm{L}_{0}(4)$ leads to a permutation of the rows in the matrix, and adding even - to rearrange columns. As expected,

$$
\mathrm{L}_{\Sigma}^{\mathrm{m}}(4)=\mathrm{L}_{0}\left(\mathrm{n}^{2}\right)+\left.\mathrm{C}_{\mathrm{m}}\right|_{\mathrm{m}=\mathrm{n}^{2}}=\mathrm{L}_{0}(\mathrm{~m})
$$

Note that the rule of cyclic ranking of natural numbers used here allows us to consider the summation of matrices with constants $m>n^{2}$. However, one should keep in mind that the structures of the resulting matrices will be repeated with the cycle $m=n^{2}$.

\section{Evolution operations for harmonic, G chaotic and hybrid oscillations}

Before turning to the analysis of vibration processes in matrix structures, we present several general combinatorial characteristics for the structures under consideration. It is known from the theory of discrete mathematics that Latin square sexist for any $\mathrm{N}=\mathrm{n}^{2}$, moreover, the exact formula for the number of Latin square
L(N)N-th order not yet established. However, from the monograph [5] bilateral estimates of the quantity are known as $\mathrm{L}(\mathrm{N})$ :

$$
\frac{(\mathrm{N} !)^{2 \mathrm{~N}}}{\mathrm{~N}^{\mathrm{N}^{2}}} \leq \mathrm{L}(\mathrm{N}) \leq \prod_{\mathrm{k}=1}^{\mathrm{N}}(\mathrm{k} !)^{\mathrm{N} / \mathrm{k}} .
$$

The exact values of the number $\mathrm{L}(\mathrm{N})$ are determined only for the values $\mathrm{N} \in[1 ; 11]$. For example, from [6] this value for the case $\mathrm{N}=9$ has the value: $\mathrm{L}(9)=5524751496156892842531225600 \approx 5.525 \times 10^{27}$.

Of course, the number of exact values $L_{s}(N)$ of different Sudoku matrix grids will be less than the total number for Latin squares $\mathrm{L}(\mathrm{N})$, if only because the number of matrices containing small squares must be excluded from $\mathrm{L}(\mathrm{N})$, which contradicts the third additional Sudoku rule (1). For example, according the third rule of (1) number of different Sudoku nets, according [7], decreases to

$$
\mathrm{L}_{\mathrm{s}}(9)=6670903752021072936960 \approx 6.671 \times 10^{21} .
$$

But quite often, we can get one Sudoku grid from another using simple transforms. Two Sudoku meshes are called equivalent if it is possible to transform one of them into another by applying one (or more than one) of the symmetries of the set G. If none of the symmetry sequences transforms one of the grids into another, the grids are called significantly different. Moreover, it is believed that the symmetry group $G$ is generated by transformations of the following types:

1) reassignment of nine digits;

2) permutation of three stacks;

3) rearrangement of three bands;

4) permutation of three columns in any stack;

5) permutation of three lines in any strip;

6) all mirror flections and rotations from the set of symmetries of the square ( 0 degree rotation - neutral element; 90 degree clockwise rotation; 180 degree clockwise rotation; 270 degree clockwise rotation; horizontal axis reflection, which goes through the square center; vertical axis reflection, which goes through the square center; reflection about the square diagonal from its lower left to upper right; reflection about the square diagonal from its upper left to lower right).

For example, using the methods of group theory, taking into account the indicated set of symmetries, the number $\mathrm{L}_{b}(9)$ of essentially different Sudoku nets was found in [7], which significantly less than the number $\mathrm{L}_{\mathrm{s}}(9)$ and equals $\mathrm{L}_{b}(9)=5472730538 \approx 5.473 \times 10^{9}$. Estimates $L_{s}(N)$ and $L_{b}(N)$ are of fundamental interest in the analysis of possible transformations of matrix structures that obey Sudoku rules.

In the previous part in proof the theorem on the property of additive conservation of grid shapes to $\mathrm{Su}$ doku requirements, that when summing matrices with constants $m>n^{2}$ of structures will be repeat with the 
cycle $m=n^{2}$. Based on this property, an operator of the evolution of their states can be introduced to describe vibration processes in matrix structures. That is, it is possible to formulate a rule of dynamics, according to which a discrete system in time steps will change the form of its structural filling to a new form from the set $L_{s}(N)$, essentially meaning her different states. In other words, it is possible to set a specific trajectory of changes in the original Sudoku grid in discrete time, which corresponds to the oscillatory process in this structure. In this case, it is necessary to associate a formal mathematical operation of digital permutations with a specific type of physical structural changes.

To this end, in [3] models of evolution operators were introduced, defined as group of (simultaneous for all digits, which fill the matrix) shift of matrix elements and the necessary transformation of matrix structures in the next step of their temporal evolution their time evolution. In this case, two types of such operators can be realized: linear-type displacements and vortex-type displacements, which we will consider below with specific examples.

Without loss of generality, we assume that the elements of the first row of the original matrix (Fig. 3, a) shift to the left one cycle position, as shown in Fig. 4, a top row of arrows. In this case, the number 2 goes to the first cell of the line, the number 3 to the second, and each subsequent one to the left of it. In place of item $\mathrm{n}^{2}$ (according to the condition of cyclic ranking) will be 1 . We will call such a cyclic permutation of elements a linear type shift. It is convenient to describe it in the form of a vector, in which pairs of numbers will be components. The first digit will be the one that is subject to change, and the second - this is a figure that is inserted in place of the variable. In our case, such a transformation vector will have the following form: $\overrightarrow{\mathrm{T}}\left\{(1,2) ;(2,3) ;(3,4) \ldots\left(\mathrm{n}^{2}, 1\right)\right\}$. We emphasize that the group permutation described by such a vector is applied to all elements of the matrix structure, and not just to the elements of the first row.

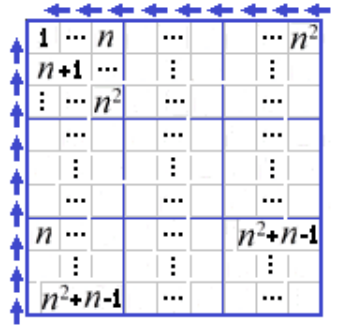

a)

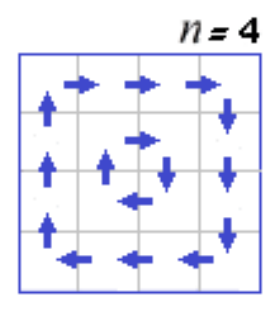

b)
Fig. 4. Types of shift operators

For example, when choosing $\mathrm{n}=3$ and the initial matrix in the form of Fig 3, c. As a result, we obtain a new matrix form, presented in Fig. 5, a.

\begin{tabular}{|l|l|l|l|l|l|l|l|l|}
\hline 2 & 3 & 4 & 5 & 6 & 7 & 8 & 9 & 1 \\
\hline 5 & 6 & 7 & 8 & 9 & 1 & 2 & 3 & 4 \\
\hline 8 & 9 & 1 & 2 & 3 & 4 & 5 & 6 & 7 \\
\hline 3 & 4 & 5 & 6 & 7 & 8 & 9 & 1 & 2 \\
\hline 6 & 7 & 8 & 9 & 1 & 2 & 3 & 4 & 5 \\
\hline 9 & 1 & 2 & 3 & 4 & 5 & 6 & 7 & 8 \\
\hline 4 & 5 & 6 & 7 & 8 & 9 & 1 & 2 & 3 \\
\hline 7 & 8 & 9 & 1 & 2 & 3 & 4 & 5 & 6 \\
\hline 1 & 2 & 3 & 4 & 5 & 6 & 7 & 8 & 9 \\
\hline
\end{tabular}

a)

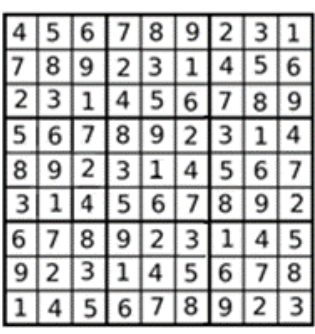

b)
Fig. 5. Type of structure as a result of linear shifts for $n=3$

In any case, as expected (according to the property of additive conservation of grid shapes to Sudoku requirements), the new matrix structure for random $\mathrm{N}=\mathrm{n}^{2}$ will be different from the original matrix only by rearranging the left column of the original matrix on its right edge. Note that such a transformation is one of the symmetry transformations from the $\mathrm{G}$ group, which leads to an equivalent grid for the original from the set $\mathrm{L}_{\mathrm{s}}(\mathrm{N})$.

The result of a linear shift of elements in a column of matrix structures is not entirely obvious. As an example, we select the first left column in the original structure and make a cyclic shift of the elements up, as shown at the Fig. 4, a side arrows. In this case when choosing $\mathrm{n}=3$ and source matrix like at Fig. 3, c the transformation vector will be: $\overrightarrow{\mathrm{T}}\{(1,4) ;(4,7) ;(7,2)$; $(2,5) ;(5,8) ;(8,3) ;(3,6) ;(6,9) ;(9,1)\}$, and the form of the transformed matrix as on Fig. 5, b. Analyzing the obtained structure here, one can notice, that it differs from the original permutation of the first left stack of the original matrix to its right edge and the subsequent two reassignments of numbers: 2 and 1, 3 and 1 . That is, for the linear shift operator in the column, we obtain a certain sequence of symmetry transformations from the group $\mathrm{G}$, which also reduces the original matrix to an equivalent grid of $L_{s}(9)$. Of course, this conclusion will also be valid for matrix structures of arbitrary size $\mathrm{N}=\mathrm{n}^{2}$.

The considered principle of constructing a structure evolution operator in the form of a linear group shift is equivalent in relation to any choice of the base row or column number in sourse matrix $L_{s}(N)$. Of course, in this case the directions of the slides and opposite to the analyzed ones can be chosen. However, as shownin [3], the possibilities of introducing operators of the evolution of structures in the form of cyclic shifts, in which the shapes of Sudoku grids are preserved, are not limited to these options. The second type of evolution on operators can be defined based on vortex shifts. In this case, the elements of an arbitrarily selectedsmall square $\mathrm{n} \times \mathrm{n}$ the original structure is shifted along the perimeter of the square, for example, clockwise around its center, as shown in Fig. 4, b internal arrows for a special case $n=4$. Note, that here even $n$ is full transfor- 
mation of square elements and for the odd values - the central cell will pass into itself. When we choose $n=3$ and central small square as a basis in the matrix Fig. 3, c transformation vector is: $\overrightarrow{\mathrm{T}}\{(1,7) ;(2,3) ;(3,4) ;(4,1)$; $(5,8) ;(6,5) ;(7,6) ;(8,2) ;(9,9)\}$ and Fig. 6, a represented the view of the transformed matrix is shown on Fig. 6, a. An analysis of the resulting matrix structures shows, that it what should be attributed for the $\mathrm{L}_{b}(\mathrm{~N})$ set significantly different grids with respect to the original. Of course, when choosing any direction of contour shift (clockwise or counterclockwise) in an arbitrary basic small square, a similar result of matrix transformation will be provided.

\begin{tabular}{|l|l|l|l|l|l|l|l|l|}
\hline 7 & 3 & 4 & 1 & 8 & 5 & 6 & 2 & 9 \\
\hline 1 & 8 & 5 & 6 & 2 & 9 & 7 & 3 & 4 \\
\hline 6 & 2 & 9 & 7 & 3 & 4 & 1 & 8 & 5 \\
\hline 3 & 4 & 1 & 8 & 5 & 6 & 2 & 9 & 7 \\
\hline 8 & 5 & 6 & 2 & 9 & 7 & 3 & 4 & 1 \\
\hline 2 & 9 & 7 & 3 & 4 & 1 & 8 & 5 & 6 \\
\hline 4 & 1 & 8 & 5 & 6 & 2 & 9 & 7 & 3 \\
\hline 5 & 6 & 2 & 9 & 7 & 3 & 4 & 1 & 8 \\
\hline 9 & 7 & 3 & 4 & 1 & 8 & 5 & 6 & 2 \\
\hline
\end{tabular}

a)

\begin{tabular}{|l|l|l|l|l|l|l|l|l|}
\hline 4 & 8 & 2 & 3 & 6 & 7 & 1 & 5 & 9 \\
\hline 3 & 6 & 7 & 1 & 5 & 9 & 4 & 8 & 2 \\
\hline 1 & 5 & 9 & 4 & 8 & 2 & 3 & 6 & 7 \\
\hline 8 & 2 & 3 & 6 & 7 & 1 & 5 & 9 & 4 \\
\hline 6 & 7 & 1 & 5 & 9 & 4 & 8 & 2 & 3 \\
\hline 5 & 9 & 4 & 8 & 2 & 3 & 6 & 7 & 1 \\
\hline 2 & 3 & 6 & 7 & 1 & 5 & 9 & 4 & 8 \\
\hline 7 & 1 & 5 & 9 & 4 & 8 & 2 & 3 & 6 \\
\hline 9 & 4 & 8 & 2 & 3 & 6 & 7 & 1 & 5 \\
\hline
\end{tabular}

b)
Fig. 6. Type of structures as a result of vortex shifts for $n=3$

Thus, in common case will it can be argued, that:

1) the introduced linear shift group evolution operators lead to matrix transformations of Sudoku nets from $[\mathrm{Ls}(\mathrm{N})-\mathrm{Lb}(\mathrm{N})]$ set - equivalent grids with respect to the original ones and can be defined as linear operators;

2) the introduced evolution operators of vortextype group shifts lead to matrix transformations of $\mathrm{Su}$ doku nets from $\mathrm{L}_{b}(\mathrm{~N})$ set significantly different grids with respect to the original ones and can be defined as nonlinear operators.

Requiring the execution of a given sequence of introduced operators, one can establish a specific scenario for dynamically changing the state of a structure on a discrete time scale. One of the options for such scenarios of fundamental interest is the implementation of a sequence of cyclic group shifts in the structure. In this case, it becomes possible to build a model of oscillatory processes in discrete structures [3]. We will verify this by analyzing the sequence of linear shifts of the first line of the original structure, shown at Fig. 3, a. We assume that the transformation with the vector considered above $\overrightarrow{\mathrm{T}}\left\{(1,2) ;(2,3) ;(3,4) \ldots\left(\mathrm{n}^{2}, 1\right)\right\}$ will be the first step in a dynamic scenario, which leads to a simple permutation of the first (left) column of the original matrix on its right edge. We perform further sequentially $\left(n^{2}-1\right)$ transformations, given by the same vector, which at each step provides the implementation of the permutation of the left column of the matrix on its right edge. Finally, such a cycle from $\mathrm{n}^{2}$ permutations we return to the original matrix. Next, execute the loop from $\mathrm{n}^{2}$ consecutive shifts in the opposite direction with the transformation vector $\overrightarrow{\mathrm{T}}\left\{(2,1) ;(3,2) ;(4,3) \ldots\left(\mathrm{n}^{2}, 1\right)\right\}$ which will provide permutations of the right column of the original matrix to its left edge. As a result of the full cycle of $2 n^{2}$ of the above steps, we again return to the original structure. In the case of repeating the sequence using the evolution operators on a homogeneous time grid several times, we obtain a model of periodic oscillations in a discrete structure.

The described approach can be easily generalized to any of the types of considered group shift operators. For clarity, at Fig. 7 schematic examples of oscillatory processes in matrix structures are given with $n=3$ (Fig. 7, a-fluctuations in the lines of the matrix structure, Fig. 7, b-fluctuations in the columns of the matrix structure, Fig. 7, c-swirl type vibrations):

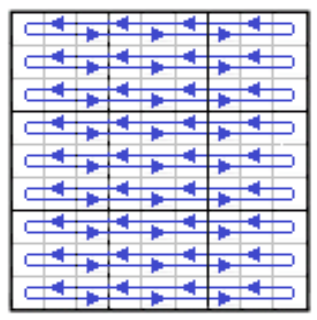

a)

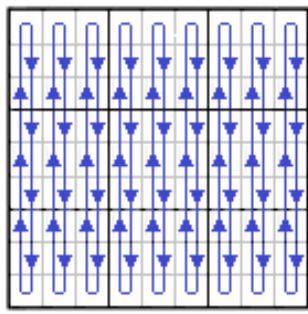

b)

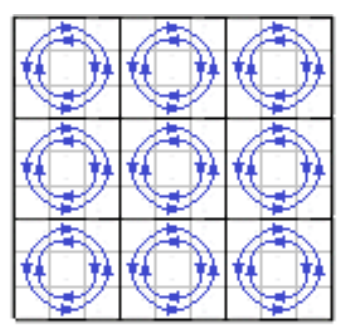

c)
Fig. 7. Modeling of oscillatory processes in a discrete structure $n=3$

Hovewer, as indicated in [3], the nature of the transformation of states in vibrations of matrix structures that are specified by linear and nonlinear type shift operators turns out to be significantly different. Moreover, nonlinear-type operators make it possible to observe manifestations of deterministic chaos in a temporary change of state of structures.

Here, to observe such chaotic manifestations, it is impossible to introduce an analog of the phase space traditionally used in the analysis of continuous-time systems. Moreover, given the Sudoku rules for uniform dispersionelements (numbers) in discrete structure, probabilistic analysis approaches become ineffective here. Therefore, as in [3], in this paper the principle of maintaining the cyclic ranking of digital sequences will be used to indicate the ordering of the structure 
$1,2, \ldots, \mathrm{n}^{2}$ in matrix structure rows, which was provided when filling in the original standard grid (Fig. 3, a). Moreover, one or another change in the order of numbers in the ranked sequences will be interpreted as a violation of order in the discrete system as a whole, and their disordered distribution among the elements of the matrix structure as a manifestation of deterministic chaos [8].

From these positions, returning to the analysis of the results of transformations as a result of group linear shifts (Fig. 5), we can indicate that:

- the introduced linear type evolution operators do not change the general order of the initial standard structure (Fig. 5, a);

- these changes are local in nature (Fig. 5, b) of the position of the elements with the number 1 .

Summarizing it can be argued that when modeling oscillatory processes in discrete structures of arbitrary size $\mathrm{N}=\mathrm{n}^{2}$ using linear-type group shift operators, chaotic manifestations are not observed. These conclusions were confirmed by a series of selective simulations of oscillatory processes in matrix structures with different $\mathrm{N}=\mathrm{n}^{2}$, similar to the schemes shown in Fig. 7 .

A completely different situation is manifested in the case of the use of nonlinear group shift operators. For example, анализируя в случае $n=3$ (Fig. 3, c) kind of structures at Fig. 6, we no longer observe in the rows of the matrix the fulfillment of the principle of ranking of digital values. However, it is clear that if at the first step we apply the transformation vector and then (clockwise) continue the sequence of 8 transformations defined by the same vector $\overrightarrow{\mathrm{T}}\{(1,7) ;(2,3) ;(3,4) ;(4,1)$; $(5,8) ;(6,5) ;(7,6) ;(8,2) ;(9,9)\}$, we will return to the original ordered matrix form. Moreover, at any step (except for the original standard grid), the principle of ranking digital values will not be performed row by row in matrices. As an example, at Fig. 6, b shows the matrix structure at the 7 th (last but one in the cycle) step. Therefore, it can be argued that when modeling vortextype oscillations (Fig. 7, c) in a discrete structure, the relative order is lost and manifestation of deterministic chaos is observed. Moreover, 9 cyclic sequences of significantly different Sudoku nets in this case will be similar to the trajectories of strange attractors on a discrete time scale. Since these attractors cannot have a sensitive dependence on the initial conditions, most of all, they should be classified as strange non-chaotic attractors [9]. It is easy to verify that the results obtained for $n=3$ remain valid for an arbitrary size of Sudoku nets.

Thus, summary, during evolutions on a uniform time scale, linear group shift operators allow us to simulate the process of linear harmonic oscillations in discrete structures of Sudoku type of arbitrary size $\mathrm{N}=\mathrm{n}^{2}$, and vortex shift operators - chaotic nonlinear oscilla- tions [10]. Of course, both linear and nonlinear operators can be sequentially used at different time stages of the evolution of matrix structures. In this case, we will be able to simulate the structural vibrations of the hybrid type. Such modeling is more general and requires a separate study, however, its application will be based on the basic principles discussed above. Here we analyze only one aspect of hybrid oscillations, which is of rather great fundamental and practical interest.

This aspect concerns the well-known problem of synchronization of deterministic chaos processes, which has been most fully investigated in the field of radio communication technologies (for example, [11-13]). Without delving into special issues, we note that in order to use chaos as an information carrier, there is a need for technical solutions that allow you to generate a chaotic signal and reproduce it with a sufficient degree of accuracy on the receiving side (that is, synchronize the processes of signal generation and reception). Here the wording of the synchronization question will be understood as follows: «is it possible to establish a connection (at least in a particular case) between a pair of matrix structures, having different chaotic digital padding?».

As it turned out, such an opportunity exists. The justification for this possibility directly follows from the theorem proved above on the property of additive conservation of grid shapes to Sudoku requirements. Really, according the theorem matrix sum of arbitrary Sudo$\mathrm{ku}$ grid $\mathrm{N}=\mathrm{n}^{2}$ size and the constant $\mathrm{C}_{\mathrm{m}}$ for $1 \leq \mathrm{m} \leq \mathrm{n}^{2}$, found taking into account the cyclic ranking rule, complies with Sudoku mandatory requirements. Note, that the addition of the same constant to each element of the original matrix in no way changes the difference relation between adjacent digital values of the elements and leads the original matrix to the equivalent grid. And this means that if the original matrix had random digital filling, then the final one will also be characterized by random type filling. For example, in the particular case of choice $\mathrm{n}=3$ and summing the original matrix structure, at Fig. 6, a, with constant matrix $\mathrm{C}_{2}$ we get.

As can be seen from the analysis of identity (7), the resulting matrix describes a new hybrid structural vibration and, as the original matrix, is characterized by chaotic digital filling. Another words, the mathematical operation of summing the initial matrix structure and the matrix constant allows you to synchronize two different chaotic evolutionary states of the structure. The specific value of the constant appearing in such a summation should be considered as a synchronization parameter for a pair of chaotic structural states. We point out that since any of a number of constants can be used in the summation: $\mathrm{C}_{\mathrm{m}}$ for $1 \leq \mathrm{m} \leq \mathrm{n}^{2}$, then is exist the possibility of parallel synchronization $\left(n^{2}-1\right)$ of the number of flows of chaotic structural evolutions. 


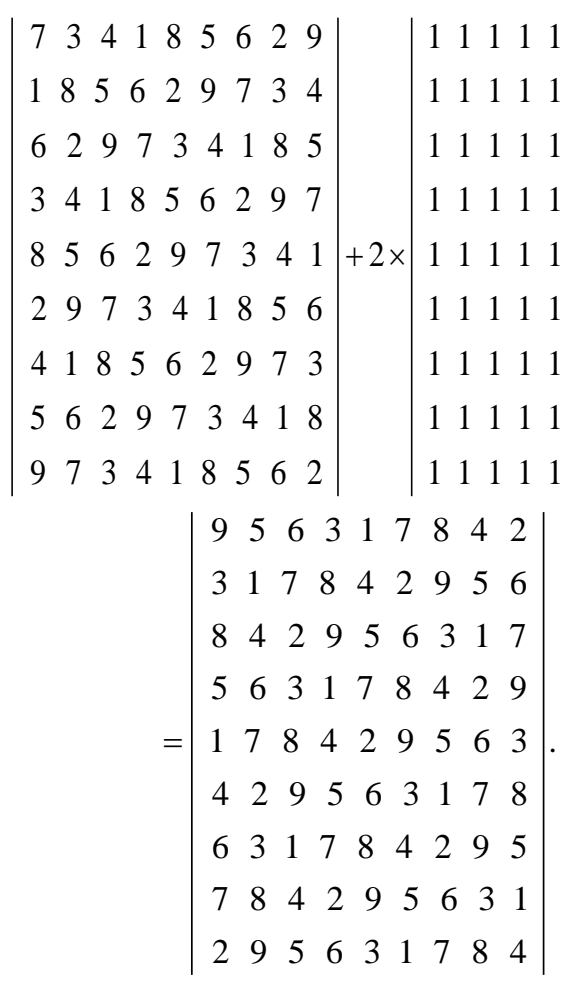

\section{Modeling of beats of oscillations in a discrete structure}

In the modern informational technologies chaos is seen as a medium of information, as dynamic process, which transforming information to a new kind, and, lastly, as a combination of both $[12,13]$. Anyway, the functionality of using controlled chaotic algorithms can be significantly expanded if any hardware capabilities for synchronizing them are known (and out of sync). In contrast to the material discussed in the previous section, the principle of synchronization of matrix structures based on digital processing, for hardware applications, it is necessary to associate the proposed mathematical models with a specific type of physical structural changes. Therefore, the purpose of this section is to develop the proposed approach for describing free vibrations in Sudoku matrix networks on discrete cellular structures in the form of two-level matrix forms in which it is possible to observe the effects of beating vibrations. Without loss of generality, here we present an analysis for the matrix structures of classical Sudoku with dimension $n=3$.

Here, as before, we will assume that the initial structure of the discrete dynamic system is given on the Sudoku grid in the ranked form shown on Fig. 4, a. The structure evolution operators will also determine the transformation of the matrix, in which the permutations of its elements (digits) obey the scripts of group shifts of linear or vortex types. Recall, that using the introduced evolution operators, a simulation of the oscillatory pro- cess of a given type for a discrete structure can be realized in the form of a chain of cyclic changes in its states. However, to observe the effect of beating oscillations, according to the general theory of signals, two oscillations at different frequencies must be simultaneously excited in a dynamic system. In this regard, it turns out to be necessary to introduce the cellular structure of a more complex organization.

It is proposed to use a layer of cubic cells enclosed between two complementary Sudoku nets of the following type as a model of such a discrete structure:

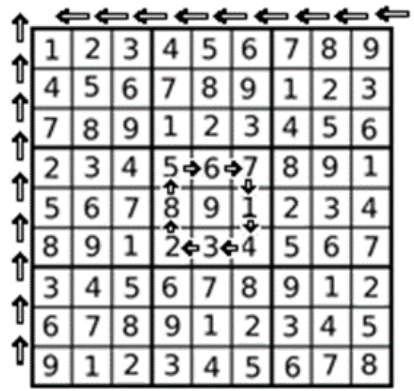

a)

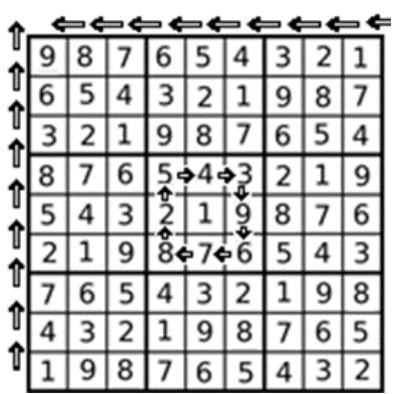

b)
Fig. 8. Original complementary matrix structures

Here, we call complementary a pair of Sudoku nets (Fig. 8), which, when superimposed on each other, provide in each cell located in the layer between them a sum of digits (or the number of inclusions) equal to 10 , as shown in Fig. 9. In the initial state, the cell structure will be characterized by a uniform distribution of inclusions across the cells of the entire layer.

\begin{tabular}{|c|c|c|}
\hline 9 & 7 & 4 \\
\hline 8 & 6 & 3 \\
\hline 1 & 5 & 2 \\
\hline 10 & 10 \\
\hline 10
\end{tabular} \mid \begin{tabular}{|c|c|c|c|}
\hline 6 & 3 & 1 \\
\hline 7 & 4 & 2 \\
\hline 8 & 5 & 9 \\
\hline
\end{tabular}

Fig. 9. Fragment of a two-layer matrix form

In the considered variant of the two-level structure, the upper grid is selected in the form shown on Fig. 8, a, and the lower grid (complementary to the upper) - in the form shown on Fig. 8, b. Then the model will provide an opportunity to analyze two independent vibrations (respectively) in each grid structure, in the form of the result of their superposition according to estimates of changes in the uniformity of filling of layer cells between vibrations.

Before proceeding to the analysis of the effect of beats for different types of oscillations, one should indicate the general characteristic property of the model 
used for the discrete structure. Without resorting to computer modeling, it is easy to make sure that if the same type of oscillations is excited in both boundary grids synchronously in time (that is, described by the same group shift operators), homogeneity of filling the cells of the model layer is maintained. Indeed, in this case, the transformed lower grid remains complementary to the transformed upper boundary grid at each discrete time step of their cyclic changes.

To observe the beats, we first consider two oscillations defined on the basis of the linear group shift operator of the first row of the matrix, as shown at Fig. 8, a top row of arrows.

To the original top model grid (Fig. 8, a) apply the evolution operator $\overrightarrow{\mathrm{T}^{\mathrm{e}}}\{(1,2) ;(2,3) ;(3,4) ;(4,5) ;(5,6)$; $(6,7) ;(7,8) ;(8,9) ;(9,1)\}$, and to the bottom (Fig. 8, b) the operator $\overrightarrow{\mathrm{T}^{\mathrm{i}}}\{(9,8) ;(8,7) ;(7,6) ;(6,5) ;(5,4) ;(4,3)$; $(3,2) ;(2,1) ;(1,9)\}$.

To ensure the mode of different frequencies of grid vibrations, we assume that transformations in the upper grid occur on each discrete interval $\mathrm{P}$ of a uniform time scale, and transformations in the lower grid on each pair (2P) of such intervals (i.e. twice as slow). Of course, at the 18th step of evolution (appropriate time 18P) discrete structure will again return to the state of uniform filling of the model layer.

Deviations from the homogeneous state (for which exactly 10 objects are located in each cell of the structure) will be observed cell-by-cell, understanding that in the cells of a layer of a two-level structure with the same upper digit at a given moment in time there will be the same number of inclusions. Therefore, it turns out to be sufficient to observe changes in the number of objects only in 9 cells of the layer located under the digital values $M=1,2, \ldots 9$ on the upper grid. It is convenient to present the observation results for analysis in a two-way table. So in Table 1 shows the number of inclusions in the cells of a two-level structure in time steps $\mathrm{I}=1,2,3, \ldots, 18$ for the considered case of addition of oscillations.

Table 1

The number of inclusions in the cells of the structure with a superposition of vibrations

\begin{tabular}{|c|c|c|c|c|c|c|c|c|c|}
\hline № & $\mathbf{1}$ & $\mathbf{2}$ & $\mathbf{3}$ & $\mathbf{4}$ & $\mathbf{5}$ & $\mathbf{6}$ & $\mathbf{7}$ & $\mathbf{8}$ & $\mathbf{9}$ \\
\hline $\mathbf{1}$ & 2 & 2 & 3 & 3 & 4 & 4 & 5 & 5 & 6 \\
\hline $\mathbf{2}$ & 11 & 11 & 3 & 3 & 4 & 4 & 5 & 5 & 6 \\
\hline $\mathbf{3}$ & 11 & 11 & 12 & 12 & 4 & 4 & 5 & 5 & 6 \\
\hline $\mathbf{4}$ & 11 & 11 & 12 & 12 & 13 & 13 & 5 & 5 & 6 \\
\hline $\mathbf{5}$ & 11 & 11 & 12 & 12 & 13 & 13 & 14 & 14 & 6 \\
\hline $\mathbf{6}$ & 11 & 11 & 12 & 12 & 13 & 13 & 14 & 14 & 15 \\
\hline $\mathbf{7}$ & 11 & 11 & 12 & 12 & 13 & 13 & 14 & 14 & 15 \\
\hline $\mathbf{8}$ & 11 & 11 & 12 & 12 & 13 & 13 & 14 & 14 & 15 \\
\hline $\mathbf{9}$ & 11 & 11 & 12 & 12 & 13 & 13 & 14 & 14 & 15 \\
\hline
\end{tabular}

For clarity, some of the results from table 1 are shown in Fig. 10 as dotted timelines. As can be clearly seen from Table 1 and 2, and Fig. 10 it turns out that in the cell structure under $M=1$ at the first time step, the number of inclusions decreases from 10 to 2 , and then gradually increases to 10 .

Table 2

The number of inclusions in the cells of the structure with a superposition of vibrations (continue)

\begin{tabular}{|c|c|c|c|c|c|c|c|c|c|}
\hline № & $\mathbf{1 0}$ & $\mathbf{1 1}$ & $\mathbf{1 2}$ & $\mathbf{1 3}$ & $\mathbf{1 4}$ & $\mathbf{1 5}$ & $\mathbf{1 6}$ & $\mathbf{1 7}$ & $\mathbf{1 8}$ \\
\hline $\mathbf{1}$ & 6 & 7 & 7 & 8 & 8 & 9 & 9 & 10 & 10 \\
\hline $\mathbf{2}$ & 6 & 7 & 7 & 8 & 8 & 9 & 9 & 10 & 10 \\
\hline $\mathbf{3}$ & 6 & 7 & 7 & 8 & 8 & 9 & 9 & 10 & 10 \\
\hline $\mathbf{4}$ & 6 & 7 & 7 & 8 & 8 & 9 & 9 & 10 & 10 \\
\hline $\mathbf{5}$ & 6 & 7 & 7 & 8 & 8 & 9 & 9 & 10 & 10 \\
\hline $\mathbf{6}$ & 15 & 7 & 7 & 8 & 8 & 9 & 9 & 10 & 10 \\
\hline $\mathbf{7}$ & 15 & 16 & 16 & 8 & 8 & 9 & 9 & 10 & 10 \\
\hline $\mathbf{8}$ & 15 & 16 & 16 & 17 & 17 & 9 & 9 & 10 & 10 \\
\hline $\mathbf{9}$ & 15 & 16 & 16 & 17 & 17 & 18 & 18 & 10 & 10 \\
\hline
\end{tabular}

Moreover, the increase in the number of inclusions is a multiple of the time discrete $2 \mathrm{P}$, and the steps of the diagram are formed by pairs of identical values of the observed number of inclusions. A similar type of fluctuation in the number of inclusions is also observed in the cell under the value $M=1$, where this number gradually increases from 10 to 18 , and again becomes 10 at the last two time intervals $17 \mathrm{P}$ and 18P. These two kinds of fluctuations, with common signal theory analogy, can be defined as the main ones (temporal dependences forming the envelope for the amplitude of the resulting signal). In the remaining cells of the structure, hybridtype vibrations are observed. For cells under $\mathrm{M}=2$ (Fig. 10, b) in the first three time intervals, the oscillations correspond to the regime in the cell under $M=9$, and on the rest - the mode of oscillations in the cell un$\operatorname{der} M=1$. Next for cells under $M=3$ (Fig. 10, d) in the first five time discrete oscillations correspond to the mode in the cell under $\mathrm{M}=9$ and they are synchronized with the oscillation mode in the cell under $\mathrm{M}=1$.

Modes of vibrations and other hybrid species also appear, for example, in a cell under $\mathrm{M}=7$ (Fig. 10, c).

As the simulation results showed, the principle of oscillation formation under the evolution operators under consideration is also preserved under other variants of the delays in the oscillations of the lower grid relative to the rate of evolution of vibrations in the upper grid of a two-level structure. In this case, the diagrams of the main oscillations are complicated with the manifestation of periodic fragments in their form. For example, in Fig. 11 shows the diagrams of the main vibrations in the structure cells for the case when the transformations in the lower grid occur three times slower than in the upper grid. 


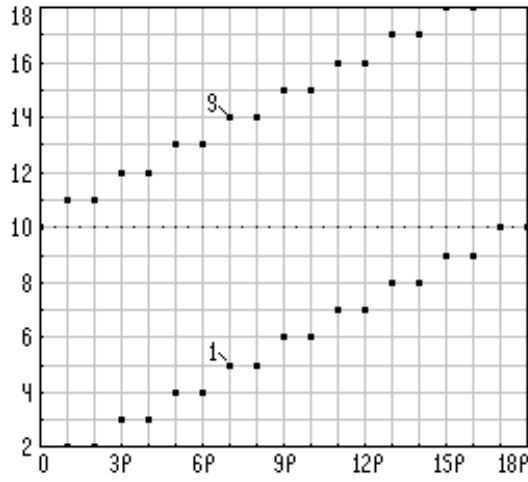

a)

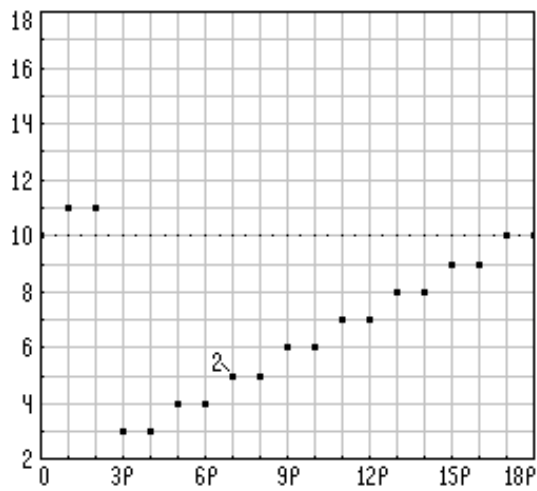

b)

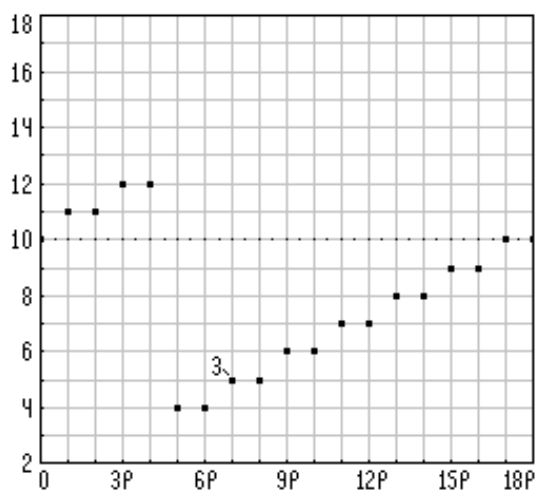

c)

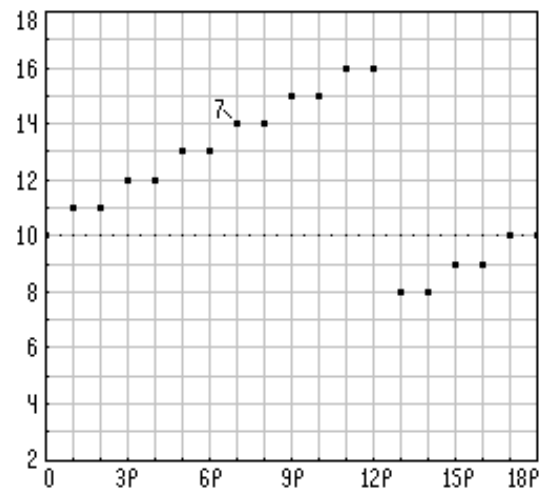

d)

Fig. 10. Frequency fluctuation diagrams $2 \mathrm{P}$

Based on the above analysis and the results of additional modeling, it can be concluded that the fluctua- tions in the number of inclusions in the structure cells, given on the basis of various linear group shift operators, for different delay intervals between transformations of the upper and lower grids of a two-level structure, are formed in the form of ordered main and hybrid fluctuations. Such a beat structure is similar to a beat process in the form of a superposition of vibrations at multiple frequencies in the theory of harmonic signals.

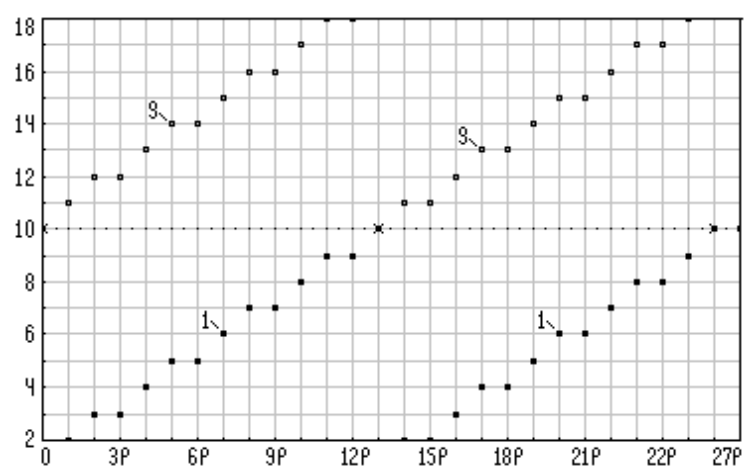

Fig. 11. Diagrams of the main fluctuations of the multiplicity $3 \mathrm{P}$

It is appropriate to note here that in the previous section it was established: as a result of group linear shifts, the introduced linear type evolution operators do not make changes to the general order of the initial grid structures, or these changes are local in nature. In this regard, it can be argued that since in the considered case the initial matrices were filled with ranked sequences of numbers (Fig. 8), then ordered oscillations were observed in the cells of the two-level structure.

When considering the vibrations specified for the boundary networks by vortex-type evolution operators, one should expect the implementation of more complex scenarios for the fluctuations in the number of inclusions in the structure cells, since, in this case, elements of deterministic chaos may appear. That is, even with the initial filling of the boundary grids with ranked sequences of digits, one should expect disordered (chaotic) forms of beatings of oscillations. These assumptions were fully confirmed by the results of multiple simulations. As an example, Table 3 and 4 shows the simulation results for the same initial boundary grids (Fig. 8) in the oscillation mode specified by the two operators of the vortex-type group shifts. It was assumed that for the upper grid, the transformation vector has the form: $\overrightarrow{\mathrm{T}^{\mathrm{e}}}\{(5,8) ;(6,5) ;(7,6) ;(8,2) ;(9,9) ;(1,7) ;(2,3) ;(3,4) ;(4,1)\}$, and for the bottom grid: $\overrightarrow{\mathrm{T}^{\mathrm{i}}}\{(5,2) ;(1,5) ;(3,4) ;(2,8)$; $(1,1) ;(9,3) ;(8,7) ;(7,6) ;(6,9)\}$.

Note that under the action of both operators, the elements of the central small squares of the original grids shift clockwise around the perimeter of the squares 
around the central digits 9 and 1, respectively. It was also assumed that transformations in the upper grid occur on each discrete interval $\mathrm{P}$ of the time scale, and transformations in the lower grid on each pair of such intervals (i.e. twice as slow). Since here the central digits of the small squares of the boundary grids are fixed, the discrete structure returns to the state of uniform filling of the model layer at the 16th step of evolution (at $\mathrm{P}=16$ ).

Table 3

The number of inclusions in the cells of the structure with noise-like beats

\begin{tabular}{|c|c|c|c|c|c|c|c|c|}
\hline № & $\mathbf{1}$ & $\mathbf{2}$ & $\mathbf{3}$ & $\mathbf{4}$ & $\mathbf{5}$ & $\mathbf{6}$ & $\mathbf{7}$ & $\mathbf{8}$ \\
\hline $\mathbf{1}$ & 7 & 7 & 8 & 8 & 9 & 9 & 3 & 3 \\
\hline $\mathbf{2}$ & 4 & 4 & 7 & 7 & 6 & 6 & 5 & 5 \\
\hline $\mathbf{3}$ & 11 & 11 & 5 & 5 & 8 & 8 & 7 & 7 \\
\hline $\mathbf{4}$ & 11 & 11 & 12 & 12 & 6 & 6 & 9 & 9 \\
\hline $\mathbf{5}$ & 9 & 9 & 8 & 8 & 14 & 14 & 11 & 11 \\
\hline $\mathbf{6}$ & 9 & 9 & 15 & 15 & 12 & 12 & 13 & 13 \\
\hline $\mathbf{7}$ & 16 & 16 & 13 & 13 & 14 & 14 & 15 & 15 \\
\hline $\mathbf{8}$ & 13 & 13 & 12 & 12 & 11 & 11 & 17 & 17 \\
\hline $\mathbf{9}$ & 10 & 10 & 10 & 10 & 10 & 10 & 10 & 10 \\
\hline
\end{tabular}

Table 4

The number of inclusions in the cells of the structure with noise-like beats (continue)

\begin{tabular}{|c|c|c|c|c|c|c|c|c|}
\hline № & $\mathbf{9}$ & $\mathbf{1 0}$ & $\mathbf{1 1}$ & $\mathbf{1 2}$ & $\mathbf{1 3}$ & $\mathbf{1 4}$ & $\mathbf{1 5}$ & $\mathbf{1 6}$ \\
\hline $\mathbf{1}$ & 6 & 6 & 5 & 5 & 4 & 4 & 10 & 10 \\
\hline $\mathbf{2}$ & 11 & 11 & 8 & 8 & 9 & 9 & 10 & 10 \\
\hline $\mathbf{3}$ & 6 & 6 & 12 & 12 & 9 & 9 & 10 & 10 \\
\hline $\mathbf{4}$ & 8 & 8 & 7 & 7 & 13 & 13 & 10 & 10 \\
\hline $\mathbf{5}$ & 12 & 12 & 13 & 13 & 7 & 7 & 10 & 10 \\
\hline $\mathbf{6}$ & 14 & 14 & 8 & 8 & 11 & 11 & 10 & 10 \\
\hline $\mathbf{7}$ & 9 & 9 & 12 & 12 & 11 & 11 & 10 & 10 \\
\hline $\mathbf{8}$ & 14 & 14 & 15 & 15 & 16 & 16 & 10 & 10 \\
\hline $\mathbf{9}$ & 10 & 10 & 10 & 10 & 10 & 10 & 10 & 10 \\
\hline
\end{tabular}

As can be seen from Table 3 and 4, the fluctuations in the number of inclusions in all cells of the structure and at all steps of evolution are disordered and their beats are chaotic. Like the general theory of signals, such beats of oscillations can be defined as noise-like. In conclusion, we note that the results obtained remain valid for matrix structures of arbitrary size.

\section{Conclusion}

In this paper the basics of a new theoretical approach for describing oscillatory processes in discrete structures of Sudoku type are presented, which expands the possibilities of modeling methods in modern discrete mathematics. Like as in [3], where the model of a simulator of oscillations in discrete structures was first proposed, which build as a classical Sudoku grid $9 \times 9$, the dynamics of evolutionary structural changes on the timeline are described by specially introduced operators of group shifts of elements of linear and vortex matrix types. Unlike from [3], this modeling approach is generalized here for matrix structures of arbitrary size. In this case, the modes of harmonic, chaotic, and hybrid oscillations are considered. On the basis of the proof of the theorem on the property of additive conservation of grid shapes to Sudoku requirements, the features of the application of structure evolution operators that provide the implementation of the considered vibration modes. Also, using this theorem, the principle of synchronization of chaotic matrix evolutions is established, which can be implemented for stable multi-threaded synchronization. The possibility of mathematical modeling of the effects of beating vibrations in discrete cellular structures organized in the form of two-level matrix forms is substantiated. On specific examples of classic Sudoku nets $9 \times 9$ size are considered the beats of oscillations in cycles of changing states of a discrete system for the two types of beating: similar to the result of a superposition of harmonic vibrations at multiple frequencies in the radio-signals theory, and noise-like beats.

General characteristics of the possibilities of the proposed modeling method are formed in the work on the basis of a comparative analysis of visual images of matrix structures. On the one side, such visualization is a qualitative advantage when studying oscillations and beats in discrete structures, like visual reproduction of the form of oscillatory processes using oscilloscopes in radio engineering measurements. On the other side, the correct comparison of matrix structures requires the use of quantitative approaches in the form of special numerical algorithms, for example, correlation analysis algorithms. The development of effective matrix comparison algorithms, including those reflecting the informational aspect of matrix fillings, should be considered as a further development of this work.

You need to understand that the main attention is paid to innovative and methodological aspects of the proposed mathematical models. Thus, the goal of most investigated examples was the rationale for this or that possibility of such modeling. These examples should not be construed as already completed studies. However the results presented here can be directly applied in the development of new cryptographic protection systems [14].

\section{References (GOST 7.1:2006)}

1. Banerjee, S. Applications of Chaos and Nonlinear Dynamics in Science and Engineering. Vol. 3 [Text] / S. Banerjee, L. Rondoni. - Springer, 2013. 303 p. DOI: 10.1007/978-3-642-34017-8.

2. Nie, X. A matrix-based approach to solving the inverse Frobenius-Perron problem using sequences of density functions of stochastically perturbed dynamical 
systems [Text] / X. Nie, D. Coca // Communications in Nonlinear Science and Numerical Simulation. - 2018. - vol. 54. - P. 248-266. DOI: 10.1016/j.cnsns. 2017.05.011.

3. Penkin, Yu. Deterministic Chaos in Vibrations of Discrete Structures of Matrix Type [Text] / Yu. Penkin, G. Khara. - Kharkiv : PIC\&T, 2018. - P. 548-552.

4. Mandelbrot, B. B. The Fractal Geometry of Nature [Text] / B. B. Mandelbrot. - N.Y. Freeman and Co., 1982. -468 p.

5. Lint, J.H. van. A Course in Combinatorics [Text] / J. H. van Lint, R. M. Wilson. - Cambridge University Press, 2001. $-602 \mathrm{p}$.

6. McKay, B. D. On the number of Latin Squares [Text] / B. D. McKay, I. M. Wanless // Annals of Combinatorics. - 2005. - Vol. 9. - P. 335-344. DOI: 10.1007/s00026-005-0261-7.

7. Russel, E. Mathematics of Sudoku II [Text] / E. Russel, A. F. Jarvis // Mathematical Spectrum. 2007. - vol. 39. - P. 54-58.

8. Лорени, Э. Детерминированное непериодическое течение [Текст] / Э. Лорени. - М. : Mup, 1981. - C. 88-117.

9. Strange attractors that are not chaotic [Text] / C. Grebogi, E. Ott, S. Pelikan, J. A. Yorke // Physica D: Nonlinear Phenomena. - 1984. - Vol. 13, iss. 1-2. - P. 261-268. DOI: 10.1016/0167-2789(84)90282-3.

10. Андронов, А. А. Теория колебаний [Текст] / A. А. Андронов, А. А. Витт, С. Э. Хайкин. - М. : Наука, 1981. - 568 c.

11. Fundamentals of Synchronisation in chaotic Systems, Concepts, and Applications [Text] / L. M. Pecora, T. L. Carroll, G. A. Johnson, D. J. Mar, J. F. Heagy // Chaos. - 1997. - vol. 7, iss. 4. - P. 520-543. DOI: $10.1063 / 1.166278$.

12. Дмитриев, А. С. Динамический хаос: новые носители информации для систем связи [Текст] / А. С. Дмитриев, А. И. Панас. - М. : Физмалит, 2002. $-252 c$.

13. Pikovsky, A. Synchronization: a universal concept in nonlinear sciences [Text] / A. Pikovsky, M. Rosenblum, J. Kurths. - Cambridge : Univ. Press, 2002. $-411 p$

14. Zeriouh, M. Cryptography Based on the Matrices [Text] / M. Zeriouh, A. Chillali, A. Boua // Boletim da Sociedade Paranaense de Matematica. - 2017. - vol. 37, iss. 3. - P. 75-83. DOI: 10.5269/bspm.v37i3.34542.

\section{References (BSI)}

1. Banerjee, S., Rondoni, L. Applications of Chaos and Nonlinear Dynamics in Science and Engineering - Vol. 3. Springer Publ., 2013, 303 p. DOI: 10.1007/978-3-642-34017-8.

2. Nie, X., Coca, D. A matrix-based approach to solving the inverse Frobenius-Perron problem using sequences of density functions of stochastically perturbed dynamical systems. Communications in Nonlinear Science and Numerical Simulation, 2018, vol. 54, pp. 248-266. DOI: 10.1016/j.cnsns.2017.05.011.

3. Penkin, Yu., Khara, G. Deterministic Chaos in Vibrations of Discrete Structures of Matrix Type. Kharkiv, PIC\&T Publ., 2018, pp. 548-552.

4. Mandelbrot, B. B. The Fractal Geometry of Nature. N.Y. Freeman and Co. Publ., 1982. 468 p.

5. Lint, J. H. van, Wilson, R. M. A Course in Combinatorics. Cambridge University Press Publ., 2001. 602 p.

6. McKay, B. D., Wanless, I. M. On the number of Latin Squares. Annals of Combinatorics, 2005, vol. 9, pp. 335-344. DOI: 10.1007/s00026-005-0261-7.

7. Russel, E., E., Jarvis, A. F. Mathematics of Sudoku II. Mathematical Spectrum, 2007, vol. 39, pp. 5458.

8. Lorentz, E. Determinirovannoe nepireodicheskoe techenie [Determined non-periodic flow], Moscow, "Mir" Publ., 1981, pp. 88-117.

9. Grebogi, C., Ott, E., Pelikan, S., Yorke, J. A. Strange attractors that are not chaotic. Physica D: Nonlinear Phenomena, 1984, vol. 13, iss. 1-2, pp. 261268. DOI: 10.1016/0167-2789(84)90282-3.

10. Andronov, A. A., Vitt, A. A., Haikin, C. E. Teoriya kolebanij [Theory of fluctuations]. Moscow, "Nauka" Publ., 1981. 568 p.

11. Pecora, L. M., Carroll, T. L., Johnson, G. A., Mar, D. J., Heagy, J. F. Fundamentals of Synchronisation in chaotic Systems, Concepts, and Applications. Chaos, 1997, vol. 7, no. 4, pp. 520-543. DOI: 10.1063/1.166278.

12. Dmitriev, A. S., Panas, A. I. Dinamicheskij haos: novye nositeli informacii dlja sistem svjazi [Dynamic chaos: new storage media for communication systems]. Moscow, "Fizmatlit" Publ., 2002. 252 p.

13. Pikovsky, A., Rosenblum, M., Kurths, J. Synchronization: a universal concept in nonlinear sciences. Cambridge, Univ. Press Publ., 2002. 411 p.

14.Zeriouh M., Chillali, A., Boua, A. Cryptography Based on the Matrices. Boletim da Sociedade Paranaense de Matematica, 2017, vol. 37, iss. 3, pp. 7583. DOI: $10.5269 / \mathrm{bspm} . v 37 i 3.34542$.

Поступила в редакцию 4.12.2019, рассмотрена на редколлегии 15.04.2020

\section{МОДЕЛЮВАННЯ ВІБРАЦЙНИХ ПРОЦЕСІВ В ДИСКРЕТНИХ МАТРИЧНИХ СТРУКТУРАХ}

Ю. М. Пенкін, Г. І. Хара, А. О. Федосеєва

Представлені загальні принципи моделювання коливань в дискретних структурах, сформувалася у вигляді спеціальних матричних форм латинського квадрата (типу Судоку). Сформульовано ознаки структурного і функціонального самоподібності для матричних структур стандартних сіток Судоку. Показано, що структурний принцип може бути інтерпретований як реалізація другої ітерації в алгоритмі масштабного 
скейлінга, характерному для фрактальних об'єктів. До ознак функціонального самоподібності структур віднесено властивість адитивного збереження форм сіток до вимог Судоку, яке сформульовано у вигляді теореми. Доведено, що матричні суми констант і сіток Судоку довільних розмірів, отримані з урахуванням введеного правила циклічного ранжирування, будуть задовольняти трьом обов'язковим вимогам Судоку. Визначено, що за допомогою виконання заданої послідовності операторів групових зрушень, можна встановити конкретний сценарій динамічного зміни станів структури на дискретній масштабі часу. Встановлено, що оператори еволюції групових зрушень лінійного типу призводять до матричних трансформацій сіток Судоку з безлічі еквівалентних (по відношенню до вихідних), а оператори групових зрушень вихрового типу - до матричних трансформацій з безлічі істотно різних сіток. Розглянуто режими гармонійних, хаотичних і гібридних коливань для структур довільного розміру. Сформульовано вимоги до перетворень оператора еволюції структур, що забезпечують реалізацію розглянутих режимів. Проаналізовано результати моделювання хаотичних коливальних процесів по циклам станів дискретної системи, що утворюють подібності аттракторних траєкторій. Встановлено принцип синхронізації хаотичних станів матричних структур. Обгрунтовано можливість симулювання режимів биття коливань в дискретних клітинних структурах, організованих у вигляді дворівневих матричних форм. На конкретних прикладах показані результати симулювання биття коливань в циклах змінюються станів дискретної системи для двох типів биття: подібних результату суперпозіціі гармонійних коливань на кратних частотах в теорії радіосигналів, а також шумоподібних биттів.

Ключові слова: дискретна структура; сітка Судоку; ознаки сапомодоби; оператори матричних трансформацій; режими коливань; детермінований хаос; шумоподібні биття.

\section{МОДЕЛИРОВАНИЕ ВИБРАЦИОННЫХ ПРОЩЕССОВ В ДИСКРЕТНЫХ МАТРИЧНЫХ СТРУКТУРАХ}

\section{Ю. М. Пенкин, Г. И. Хара, А. А. Федосеева}

Представлены общие принципы моделирования колебаний в дискретных структурах, сформированных в виде специальных матричных форм латинского квадрата (типа Судоку). Сформулированы признаки структурного и функционального самоподобий для матричных структур стандартных сеток Судоку. Показано, что структурный принцип может быть интерпретирован как реализация второй итерации в алгоритме масштабного скейлинга, характерном для фрактальных объектов. К признакам функционального самоподобия структур отнесено свойство аддитивного сохранения форм сеток к требованиям Судоку, которое сформулировано в виде теоремы. Доказано, что матричные суммы констант и сеток Судоку произвольных размеров, полученные с учетом введенного правила циклического ранжирования, будут удовлетворять трем обязательным требованиям Судоку. Определено, что с помощью выполнения заданной последовательности операторов групповых сдвижек, можно установить конкретный сценарий динамического изменения состояний структуры на дискретном масштабе времени. Установлено, что операторы эволюции групповых сдвижек линейного типа приводят к матричным трансформациям сеток Судоку из множества эквивалентных (по отношению к исходным), а операторы групповых сдвижек вихревого типа - к матричным трансформациям из множества существенно различных сеток. Рассмотрены режимы гармонических, хаотических и гибридных колебаний для структур произвольного размера. Сформулированы требования к преобразованиям операторов эволюции структур, обеспечивающих реализацию рассмотренных режимов. Проанализированы результаты моделирования хаотических колебательных процессов по циклам состояний дискретной системы, образующих подобия аттракторных траекторий. Установлен принцип синхронизации хаотических состояний матричных структур. Обоснована возможность симулирования режимов биений колебаний в дискретных клеточных структурах, организованных в виде двухуровневых матричных форм. На конкретных примерах показаны результаты симулирования биений колебаний в циклах изменяющихся состояний дискретной системы для двух типов биений: подобных результату суперпозиции гармонических колебаний на кратных частотах в теории радиосигналов, а также шумоподобных биений.

Ключевые слова: дискретная структура; сетка Судоку; признаки самоподобия; операторы матричных трансформаций; режимы колебаний; детерминированный хаос; шумоподобные биения.

Пенкин Юрий Михайлович - д-р физ.-мат. наук, доцент, профессор кафедры фармакоинформатики, Национальный фармацевтический университет, Харьков, Украина.

Хара Георгий Иванович - канд. техн. наук, доцент кафедры фармакоинформатики, Национальный фармацевтический университет, Харьков, Украина.

Федосеева Алина Александровна - канд. техн. наук, Харьковский радиотехнический колледж; Национальный аэрокосмический университет им. Н. Е. Жуковского «Харьковский авиационный институт», Харьков, Украина.

Yuriy Penkin - Doctor of Science degree, Full professor, National Pharmaceutical University, Kharkov, Ukraine, e-mail: penkin_@gmail.com, ORCID Author ID: 0000-0002-7265-0227.

Georgi Hara - PhD, National Pharmaceutical University,

e-mail: geoivn11@gmail.com, ORCID Author ID: 0000-0002-1430-0069.

Alina Fedoseeva - PhD in Computer Science, Kharkov Radiotechnical College, National Aerospace University "Kharkiv Aviation Institute", Kharkov, Ukraine,

e-mail: fedoseeva439@gmail.com, ORCID Author ID: 0000-0002-6684-5802. 